\title{
Excitotoxic Death of Retinal Neurons In Vivo Occurs via a Non-Cell-Autonomous Mechanism
}

\author{
Frédéric Lebrun-Julien, ${ }^{1 \star}$ Laure Duplan, ${ }^{1 *}$ Vincent Pernet, ${ }^{1}$ Ingrid Osswald, ${ }^{2}$ Przemyslaw Sapieha, ${ }^{1}$ \\ Philippe Bourgeois, ${ }^{1}$ Kathleen Dickson, ${ }^{3}$ Derek Bowie, ${ }^{2}$ Philip A. Barker, ${ }^{3 \#}$ and Adriana Di Polo ${ }^{1 \#}$ \\ ${ }^{1}$ Department of Pathology and Cell Biology and Groupe de Recherche sur le Système Nerveux Central, Université de Montréal, Montreal, Quebec H3T 1J4, \\ Canada, ${ }^{2}$ Department of Pharmacology and Therapeutics, and ${ }^{3}$ Centre for Neuronal Survival, Montreal Neurological Institute, McGill University, Montreal, \\ Quebec H3A 2B4, Canada
}

The central hypothesis of excitotoxicity is that excessive stimulation of neuronal NMDA-sensitive glutamate receptors is harmful to neurons and contributes to a variety of neurological disorders. Glial cells have been proposed to participate in excitotoxic neuronal loss, but their precise role is defined poorly. In this in vivo study, we show that NMDA induces profound nuclear factor $\kappa \mathrm{B}(\mathrm{NF}-\kappa \mathrm{B})$ activation in Müller glia but not in retinal neurons. Intriguingly, NMDA-induced death of retinal neurons is effectively blocked by inhibitors of NF- $\kappa$ B activity. We demonstrate that tumor necrosis factor $\alpha$ (TNF $\alpha$ ) protein produced in Müller glial cells via an NMDA-induced NF- $\kappa \mathrm{B}$-dependent pathway plays a crucial role in excitotoxic loss of retinal neurons. This cell loss occurs mainly through a TNF $\alpha$ dependent increase in $\mathrm{Ca}^{2+}$-permeable AMPA receptors on susceptible neurons. Thus, our data reveal a novel non-cell-autonomous mechanism by which glial cells can profoundly exacerbate neuronal death following excitotoxic injury.

\section{Introduction}

Glutamate is the predominant excitatory neurotransmitter in many regions of the CNS. Elevation of endogenous glutamate and activation of glutamate receptors contribute to a variety of acute and chronic neurological disorders, including hypoxicischemic brain injury (stroke), trauma, seizures, and various forms of dementia and neurodegeneration (Kalia et al., 2008). In the retina, excess glutamate has been proposed to underlie common neurodegenerative disorders, including glaucoma and retinal artery occlusion (Hare et al., 2001, 2004; Casson, 2006; Seki and Lipton, 2008). The central hypothesis for excitotoxic injury is that excess glutamate binds to cell surface NMDA receptors on neurons, triggers massive $\mathrm{Ca}^{2+}$ influx, and activates proapoptotic signaling cascades. However, NMDA antagonists have consistently failed in clinical trials (Lee et al., 1999; Ikonomidou and Turski, 2002; Kemp and McKernan, 2002), suggesting that other mechanisms contribute to the devastating excitotoxic damage that occurs in vivo.

Neighboring non-neuronal cells may facilitate neuronal damage after excitotoxic injury. For example, activated microglia and

\footnotetext{
Received Feb. 18, 2009; accepted Feb. 25, 2009.

This work was supported by independent grants to A.D.P. and P.A.B. from the Canadian Institutes of Health Research (CIHR). F.L.J. is recipient of a Fonds de recherche en santé du Québec (FRSQ) doctoral fellowship; L.D. is recipient of a Fight for Sight Postdoctoral Fellowship; I.O. is recipient of a Best and Banting CIHR doctoral fellowship; D.B. holds a Canadian Research Chair; A.D.P. holds an FRSQ Chercheur Senior Scholarship; and P.A.B holds an FRSQ Chercheur National and is a McGill Dawson Scholar. We thank Drs. Timothy Kennedy and Wayne Sossin for helpful discussions on this manuscript, and Dr. David Stellwagen for providing TNF $\alpha$ null mice.

*F.L.-J. and L.D. contributed equally to this work.

\#P.A.B. and A.D.P. are co-senior authors.

Correspondence should be addressed to Dr. Adriana Di Polo, Department of Pathology and Cell Biology, Université de Montréal, 2900, Boulevard Edouard-Montpetit, Pavillon Roger-Gaudry, Room N-535, Montreal, QC H3T 1J4, Canada. E-mail: adriana.di.polo@umontreal.ca.

DOI:10.1523/JNEUROSCI.0831-09.2009

Copyright $\odot 2009$ Society for Neuroscience $\quad$ 0270-6474/09/295536-10\$15.00/0
}

astrocytes produce proinflammatory cytokines after excitotoxic injury (Wood, 1995; Barone and Feuerstein, 1999; Jeon et al., 2008; Vogt et al., 2008). Tissue plasminogen activator derived from microglia promotes excitotoxin-induced neuronal death in the hippocampus (Tsirka et al., 1995), whereas inhibition of microglial activation and proliferation has been shown to reduce excitotoxic injury (Tikka et al., 2001). Collectively, these data support a model in which excitotoxic brain damage activates glial cells, which then enhance neuronal death. However, the molecular mechanisms by which glial cells regulate excitotoxic loss of neurons have not yet been defined. A primary aim of this study was to investigate whether non-neuronal cells play a role in excitotoxic injury in the adult retina and, if so, to define the molecular pathways by which they influence neuronal death in vivo.

A potential effector of injury in the CNS is the nuclear factor $\kappa \mathrm{B}(\mathrm{NF}-\kappa \mathrm{B})$. In non-neuronal cells, NF- $\kappa \mathrm{B}$ activates transcription of antiapoptotic genes and production of cytokines and chemokines that mediate inflammation (Hoffmann and Baltimore, 2006). NF- $\kappa$ B also plays important roles in the nervous system, both promoting neuronal survival and facilitating synaptic function (Mattson and Camandola, 2001; Meffert and Baltimore, $2005)$. The role of NF- $\kappa$ B in neuropathological settings, however, has been controversial. Several studies have indicated that NF- $\kappa \mathrm{B}$ is neuroprotective after injury (Maggirwar et al., 1998; Hamanoue et al., 1999; Bhakar et al., 2002), whereas others have shown that NF- $\kappa \mathrm{B}$ activation facilitates neuronal damage (Schneider et al., 1999; Schwaninger et al., 2006).

In this study, we report that the extensive death of retinal neurons induced by NMDA is effectively blocked with pharmacological inhibitors of NF- $\kappa \mathrm{B}$ activity. Using a transgenic NF- $\kappa \mathrm{B}$ reporter mouse, we unequivocally identify the cellular site of NMDA-induced NF- $\kappa$ B activation as Müller glial cells. Further- 


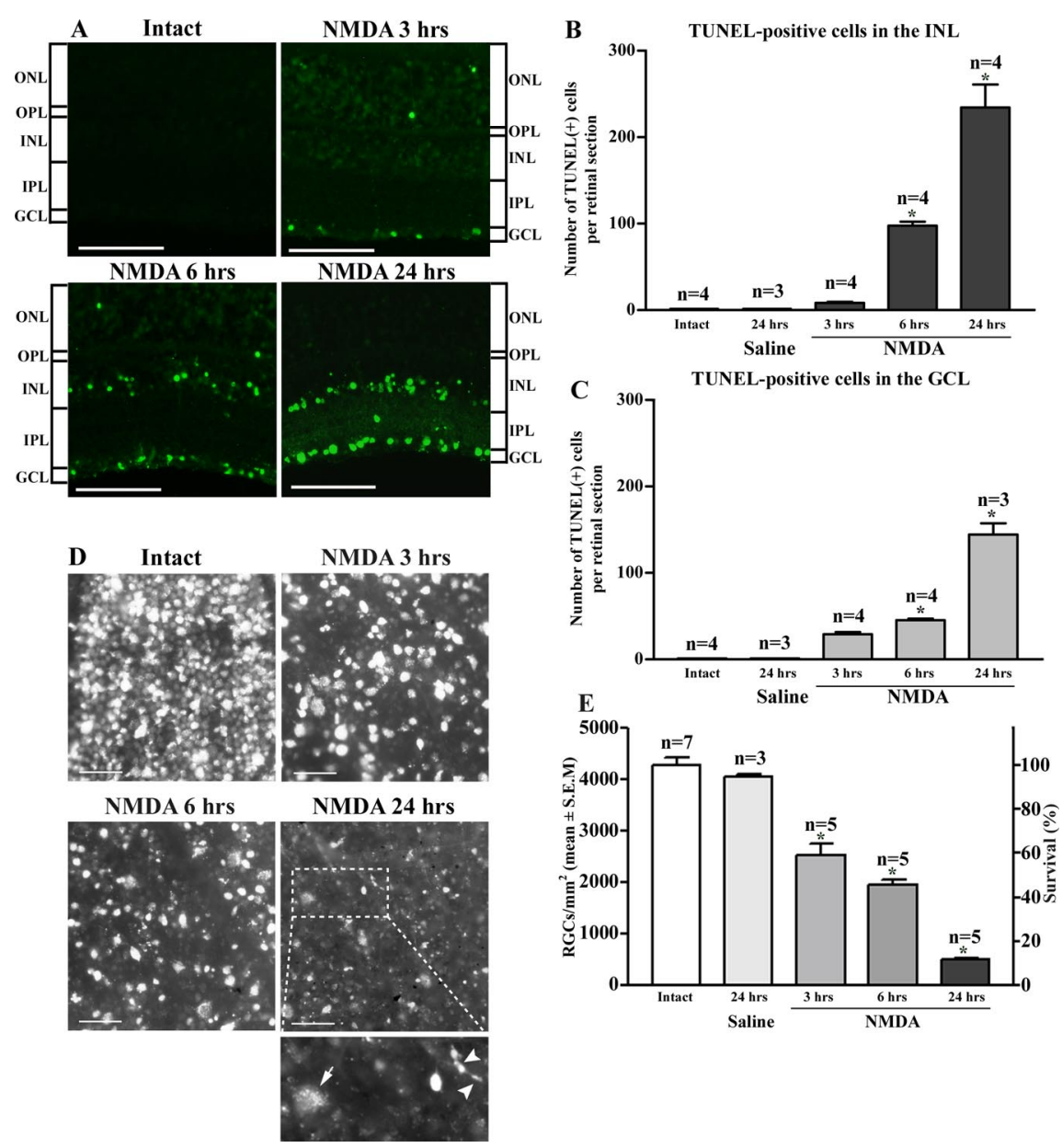

Figure 1. Retinal neurons die following intraocular injection of NMDA. $A$, Fluorescent microscopy images of retinal sections from intact or NMDA-treated eyes following TUNEL assay. $\boldsymbol{B}, \boldsymbol{C}$, Quantification of TUNEL ${ }^{+}$cells in the inner nuclear layer $(\boldsymbol{B})$ and ganglion cell layer $(\boldsymbol{C})$ demonstrated a striking increase in the number of apoptotic cells in the inner retina. $\boldsymbol{D}$, Retinal whole mounts following retrograde labeling with Fluorogold were examined to assess the density of retinal ganglion cells in intact and NMDA-treated retinas. Inset shows an example of the morphological difference between retinal ganglion cells (arrow) and fluorogold-labeled microglia (arrowheads). E, Quantitative analysis of the number of retinal ganglion cells that survived at 3, 6 , and $24 \mathrm{~h}$ after NMDA treatment. The density of retinal ganglion cells in intact, uninjured retinas is shown as reference $(100 \%$ survival; $\square$ ). Values are expressed as mean \pm SEM (ANOVA, Tukey's multiple comparison test; ${ }^{*} p<0.001$ ). 0NL, Outer nuclear layer; OPL, outer plexiform layer; INL, inner nuclear layer; IPL, inner plexiform layer; $\mathrm{GCL}$, ganglion cell layer. Scale bars, $100 \mu \mathrm{m}$ $(A), 50 \mu \mathrm{m}(D)$.

more, we demonstrate that NF- $\kappa \mathrm{B}$-dependent tumor necrosis factor $\alpha(\mathrm{TNF} \alpha)$ production by Müller cells promotes retinal ganglion cell death. Finally, we show that Müller cell-derived TNF $\alpha$ leads to neuronal loss by increasing cell surface expression of $\mathrm{Ca}^{2+}$-permeable AMPA receptors (AMPARs). Our data reveal a novel non-cell-autonomous pathway by which retinal glia can exacerbate neuronal death following excitotoxic injury.

\section{Materials and Methods}

Experimental animals

Experimental procedures were carried out on C57BL/6 transgenic or wild-type littermate control mice in accordance with the policies on the Use of Animals in Neuroscience Research and the Canadian Council on Animal Care guidelines (Olfert et al., 1993). The NF- $\kappa$ B reporter mice contain an NF- $\kappa$ B-responsive minigene composed of three tandem HIVderived $\kappa \mathrm{B}$ binding repeats placed upstream of a minimal SV 40 promoter and drive expression of an Escherichia coli $\beta$-galactosidase ( $\beta$-gal) gene tagged with a nuclear localization sequence (Bhakar et al., 2002). TNF $\alpha$ knock-out mice were kindly provided by Dr. D. Stellwagen (Montreal General Hospital, McGill University, Montreal, QC, Canada). The num- ber of animals used in each experiment $(n)$ is shown on each graph and/or in the figure legend.

\section{Intraocular injections}

NMDA (20 mm; Sigma) was injected into the vitreous chamber of the left eye using a $10 \mu \mathrm{l} \mathrm{Ham}$ ilton syringe adapted with a 32 gauge glass microneedle (total volume, $2 \mu \mathrm{l}$ ). The vitreous fluid in adult mice is estimated to range from 5 to $20 \mu \mathrm{l}$ (Remtulla and Hallett, 1985; Sharma et al., 2005; $\mathrm{Yu}$ and Cringle, 2006); therefore, the concentration of NMDA that reaches retinal ganglion cells is 2-8 mM. This amount of NMDA allows us to compare our results with previous studies using similar NMDA concentrations (Shimazawa et al., 2005; Ito et al., 2008; Nakazawa et al., 2008).

NMDA was injected alone or in combination with cell-permeable recombinant SN50 peptide $(100 \mu \mathrm{g} / \mathrm{ml}$; Biomol), SN50M $(100 \mu \mathrm{g} / \mathrm{ml}$; Biomol), PS1145 (500 $\mu \mathrm{M}$; a kind gift from Millennium Pharmaceuticals), MK-801 (1 mM; Sigma), Etanercept (Enbril; $25 \mu \mathrm{g} / \mu \mathrm{l}$; Immunex), z-IETD-fmk (50 $\mu \mathrm{M}$; Biovision), GYKI 52466 (500 $\mu$; Tocris), or IEM 13460 (500 $\mu \mathrm{M}$; Sigma). Eyes injected with vehicle (PBS), control Fc, or noninjected intact eyes served as controls. Intraocular injections were performed under general anesthesia (2\% isoflurane/oxygen mixture, $0.8 \mathrm{~L} / \mathrm{min}$ ). The needle tip was inserted into the superior hemisphere of the eye, at a $45^{\circ}$ angle through the sclera into the vitreous body. This route of administration avoided retinal detachment or injury to eye structures, including the iris and lens, which release factors that induce neuronal survival (Mansour-Robaey et al., 1994; Leon et al., 2000; Fischer et al., 2001). Surgical glue (Indermill; Tyco Health Care) was used to seal the injection site.

\section{$\beta$-gal detection}

Mice were perfused transcardially with $0.8 \%$ glutaraldehyde, and the eyes were immediately dissected out. Tissue was incubated overnight at $37^{\circ} \mathrm{C}$ in staining solution containing $5 \mathrm{~mm}$ potassium ferricyanide, $5 \mathrm{~mm}$ potassium ferrocyanide, and $1 \mathrm{mg} / \mathrm{ml}$ 5-bromo-4-chloro-3indolyl- $\beta$-galactopyranoside (Invitrogen). Tissue was embedded in optimal cutting temperature (OCT) compound (Tissue-Tek; Miles), and retinal cryosections ( $16 \mu \mathrm{m})$ were collected onto gelatin-coated slides and examined under light microscopy.

\section{Retinal immunohistochemistry}

Mice were perfused with $4 \%$ paraformaldehyde, and retinal sections were prepared as above. Tissue sections were first incubated in 3\% BSA and $0.3 \%$ Triton X-100 (Sigma) to block nonspecific binding, then incubated with primary antibody $(\mathrm{Ab})$ (see list below) overnight at $4^{\circ} \mathrm{C}$, followed by incubation with secondary $\mathrm{Ab}$ at room temperature. Slides were mounted with SlowFade (Invitrogen) and visualized on a Zeiss Axioskop 2 Plus microscope. Primary Abs used were $\beta$-gal ( $6.6 \mu \mathrm{g} / \mathrm{ml}$; Millipore Bioscience Research Reagents), cellular retinaldehyde-binding protein (1:1000; a gift from J. C. Saari, University of Washington, Seattle, WA), protein kinase C (5 $\mu \mathrm{g} / \mathrm{ml}$; BD Biosciences), calretinin $(2 \mu \mathrm{g} / \mathrm{ml}$; Millipore Bioscience Research Reagents), glial fibrillary acidic protein (2.5 $\mu \mathrm{g} / \mathrm{ml}$; Millipore Bioscience Research Reagents), and macrophage/ monocytes (MAC-1; 1:2; a gift from S. David, McGill University, Montreal, QC, Canada), and TNF $\alpha(0.4 \mu \mathrm{g} / \mathrm{ml}$; Millipore Bioscience Research Reagents). The secondary Abs used were sheep anti-mouse IgG $(1 \mu \mathrm{g} / \mathrm{ml}$; FITC conjugate; Sigma) or anti-rabbit IgG ( $1 \mu \mathrm{g} / \mathrm{ml}$; Cy3; Jackson ImmunoResearch Laboratories). 


\section{Immunoblot analysis}

Retinas were homogenized in lysis buffer and centrifuged at 10,000 rpm for $5 \mathrm{~min}$, and supernatants were collected and analyzed by SDS polyacrylamide gels and immunoblotting. Membranes were incubated with TNF $\alpha$ Ab $(0.2 \mu \mathrm{g} / \mathrm{ml}$; Millipore Bioscience Research Reagents) or $\beta$-actin $(0.5 \mu \mathrm{g} / \mathrm{ml}$; Sigma), washed in Tris-buffered saline-Tween 20, and then incubated with peroxidase-linked secondary $\mathrm{Ab}(0.5 \mu \mathrm{g} / \mathrm{ml}$; GE Healthcare). Protein signals were detected using a chemiluminescence reagent (ECL; GE Healthcare) followed by exposure of blots to X-OMAT (Kodak) imaging film.

\section{Cell survival assays and quantification}

Terminal dUTP nick end labeling. The terminal dUTP nick end labeling (TUNEL) assay (Gavrieli et al., 1992) was performed using the In Situ Apoptosis Detection Kit (Millipore Bioscience Research Reagents) on retinal cryosections following the manufacturer's instructions. TUNELpositive cells in the entire retinal section were counted on 16 sections per eye.

Retrograde labeling. Fluorogold (2\%; Fluorochrome) in $0.9 \% \mathrm{NaCl}$ was applied to the superior colliculus as described previously (Sapieha et al., 2005). The maximum number of retinal ganglion cells is observed after $7 \mathrm{~d}$ of Fluorogold application, and it is stable for several weeks thereafter (Berkelaar et al., 1994; Mansour-Robaey et al., 1994; PeinadoRamón et al., 1996; Cheng et al., 2002). Therefore, procedures were performed 1 week after Fluorogold application. Mice were perfused with 4\% paraformaldehyde; the eyes were dissected and flat-mounted vitreal side up on glass sides. Fluorogold-positive retinal ganglion cells were counted in 12 retinal zones: three areas in each eye quadrant located at $0.5,1.0$, and $1.5 \mathrm{~mm}$ from the optic nerve head were examined (Sapieha et al., 2005), corresponding to a total area of $0.5 \mathrm{~mm}^{2}$.

\section{Identification of $\mathrm{Ca}^{2+}$-permeable AMPARs}

$\mathrm{Ca}^{2+}$-permeable AMPARs were identified using the $\mathrm{Co}^{2+}$ staining technique (Osswald et al., 2007). Retinas were dissected, cut in small pieces, and incubated for $30 \mathrm{~min}$ in oxygenated assay buffer $(5 \mathrm{~mm} \mathrm{KCl}, 2 \mathrm{~mm}$ $\mathrm{MgCl}, 12 \mathrm{~mm}$ glucose, $20 \mathrm{~mm}$ bicarbonate, $139 \mathrm{~mm}$ sucrose, $57.5 \mathrm{~mm}$ $\mathrm{NaCl}$, and $0.75 \mathrm{~mm} \mathrm{CaCl}_{2}$ ). The tissue was then incubated in $5 \mathrm{~mm} \mathrm{CoCl}_{2}$ and $10 \mathrm{mM}$ L-glutamic acid in the presence or absence of AMPA receptor blockers GYKI 52466 ( $40 \mu \mathrm{M}$; Tocris) or IEM 13460 (100 $\mu \mathrm{M}$, Sigma) for $15 \mathrm{~min} . \mathrm{Co}^{2+}$ was precipitated with $0.24 \%$ ammonium sulfide, and the retina was then fixed in $0.8 \%$ glutaraldehyde and $20 \mu \mathrm{m}$ sections were prepared. Silver enhancement of the $\mathrm{Co}^{2+}$ sulfide precipitate was performed using the Intense kit (GE Healthcare), then retinal sections were rinsed and mounted, and photomicrographs were captured with a Zeiss Axioplan 2 imaging microscope.

\section{Statistical analyses}

Statistical analyses were performed using one-way ANOVA, followed by nonparametric test (Tukey's multiple comparison test) or by Student's $t$ test, as indicated in legends.

\section{Results}

\section{NMDA induces NF- $\kappa$ B-dependent death of retinal neurons}

Retinal neurons, particularly amacrine and retinal ganglion cells, are exquisitely sensitive to excitotoxicity (Siliprandi et al., 1993; Kikuchi et al., 1995; Manabe and Lipton, 2003). To dissect the signaling pathways that contribute to excitotoxic injury in the retina, we first established the time course of neuronal loss following NMDA intraocular injection. Two complementary techniques were used for quantification of neuronal cell death: TUNEL labeling on retinal cross sections, and Fluorogold retrograde labeling of retinal ganglion cells visualized on retinal whole mounts.

Figure $1 A-C$ shows that TUNEL $^{+}$cells were first detected $3 \mathrm{~h}$ after NMDA exposure, and their number increased markedly by 6 and $24 \mathrm{~h}$ after NMDA injection. TUNEL staining was observed in the inner nuclear layer, in which amacrine cells are found, and in the ganglion cell layer, in which retinal ganglion cells and displaced amacrine cells are located. Fluorogold retrograde label-
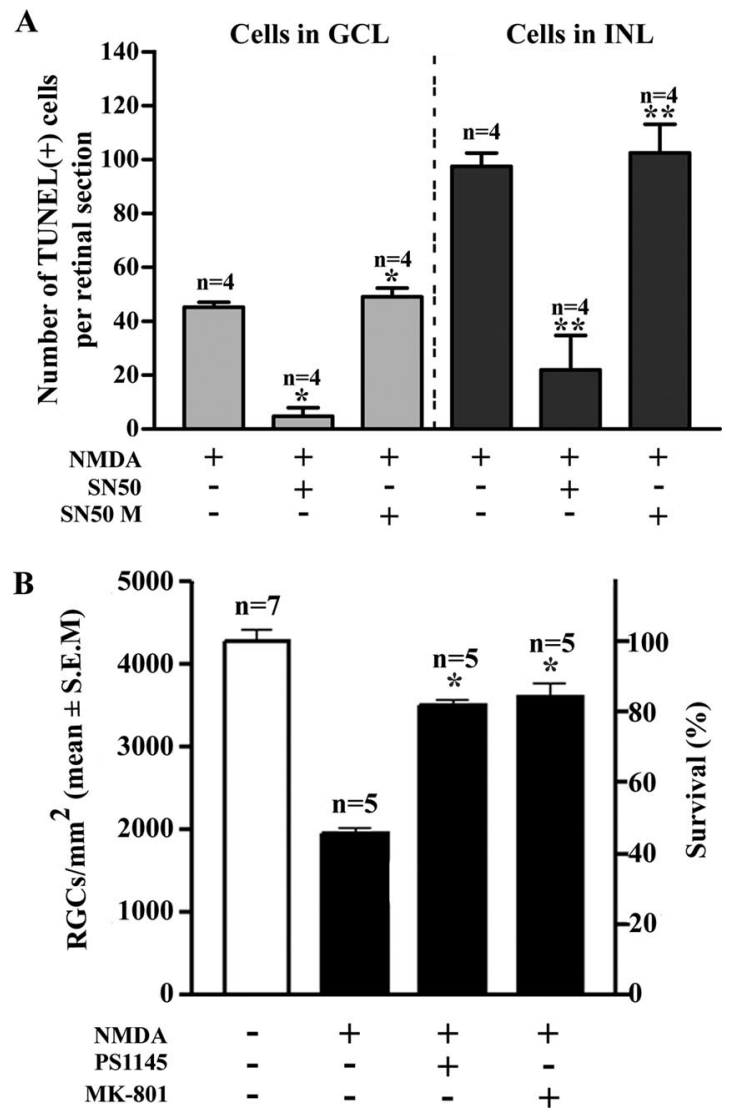

Figure 2. NMDA-induced neuronal death is NF- $\kappa$ B dependent. $\boldsymbol{A}$, Quantification of TUNEL ${ }^{+}$ cells in the inner nuclear layer (INL) or ganglion cell layer (GCL) at 6 h after treatment with NMDA alone, a mixture of NMDA and SN50, or NMDA and inactive SN50M peptide. In the presence of SN50, but not SN50M, there was a ninefold and fourfold reduction in the number of TUNEL ${ }^{+}$ cells in the ganglion cell layer and INL, respectively. Values are expressed as mean \pm SEM (ANOVA; Tukey's multiple comparison test; ${ }^{*} p<0.05$; ${ }^{* *} p<0.001$ ). $\boldsymbol{B}$, Treatment with PS1145, a small molecule inhibitor of IKK2, promoted retinal ganglion cell neuroprotection in the presence of NMDA (ANOVA; Tukey's multiple comparison test; ${ }^{*} p<0.001$ ). The neuroprotective effect of PS1145 was comparable to that of MK-801, a noncompetitive antagonist of NMDA receptors (ANOVA; Tukey's multiple comparison test; ${ }^{*} p<0.001$ ). Values are expressed as retinal ganglion cell densities (RGCs/mm ${ }^{2}$; mean \pm SEM) and are compared with intact retinas ( $100 \%$ survival; $\square$ ).

ing, performed to assess retinal ganglion cell viability, showed that NMDA injection resulted in rapid loss of these neurons: $50 \%$ of retinal ganglion cells remained at $6 \mathrm{~h}$ after NMDA exposure, while $<10 \%$ survived at $24 \mathrm{~h}$ post-NMDA treatment (Fig. $1 D, E$ ). Microglia and macrophages, which may have incorporated Fluorogold (Fluorochrome) after phagocytosis of dying retinal ganglion cells, were excluded based on morphological criteria. Microglia invariably have smaller cell size, visible process ramifications and lack axons (Thanos, 1991; Kacza and Seeger, 1997) (Fig. $1 \mathrm{D}$ inset, arrowheads). Although NMDA was administered in the dorsal (superior) retina, loss of Fluorogold-labeled retinal ganglion cells was similar between dorsal, ventral, nasal, and temporal retinal quadrants (ANOVA; $p>0.05$; supplemental Fig. 1, available at www.jneurosci.org as supplemental material). The apparent higher number of $\mathrm{TUNEL}^{+}$cells compared with Fluorogold ${ }^{+}$cells in the ganglion cell layer (Fig. $1 A, D ; 24 \mathrm{~h}$ ) likely reflects that this layer is composed of retinal ganglion cells and displaced amacrine cells in $\sim 1: 1$ ratio (Perry, 1981). Therefore, $\mathrm{TUNEL}^{+}$cells in the ganglion cell layer represent both retinal ganglion cells as well as displaced amacrine cells, whereas Fluorogold labels only retinal ganglion cells. 

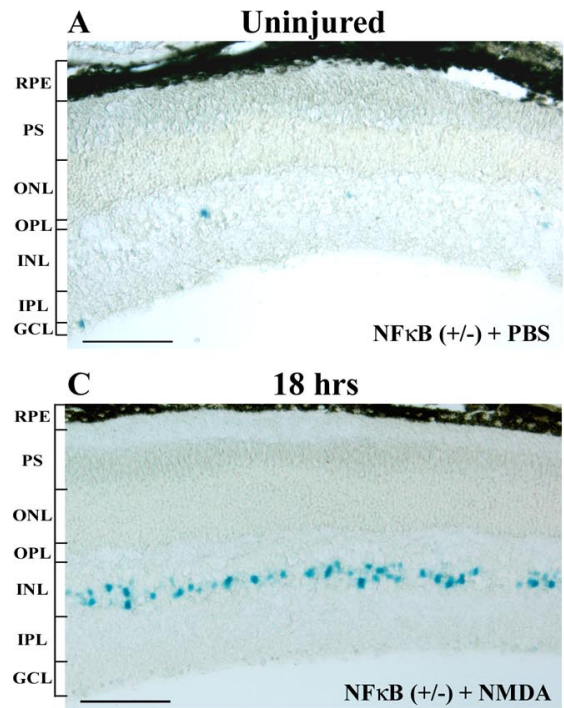

$\mathbf{E}$
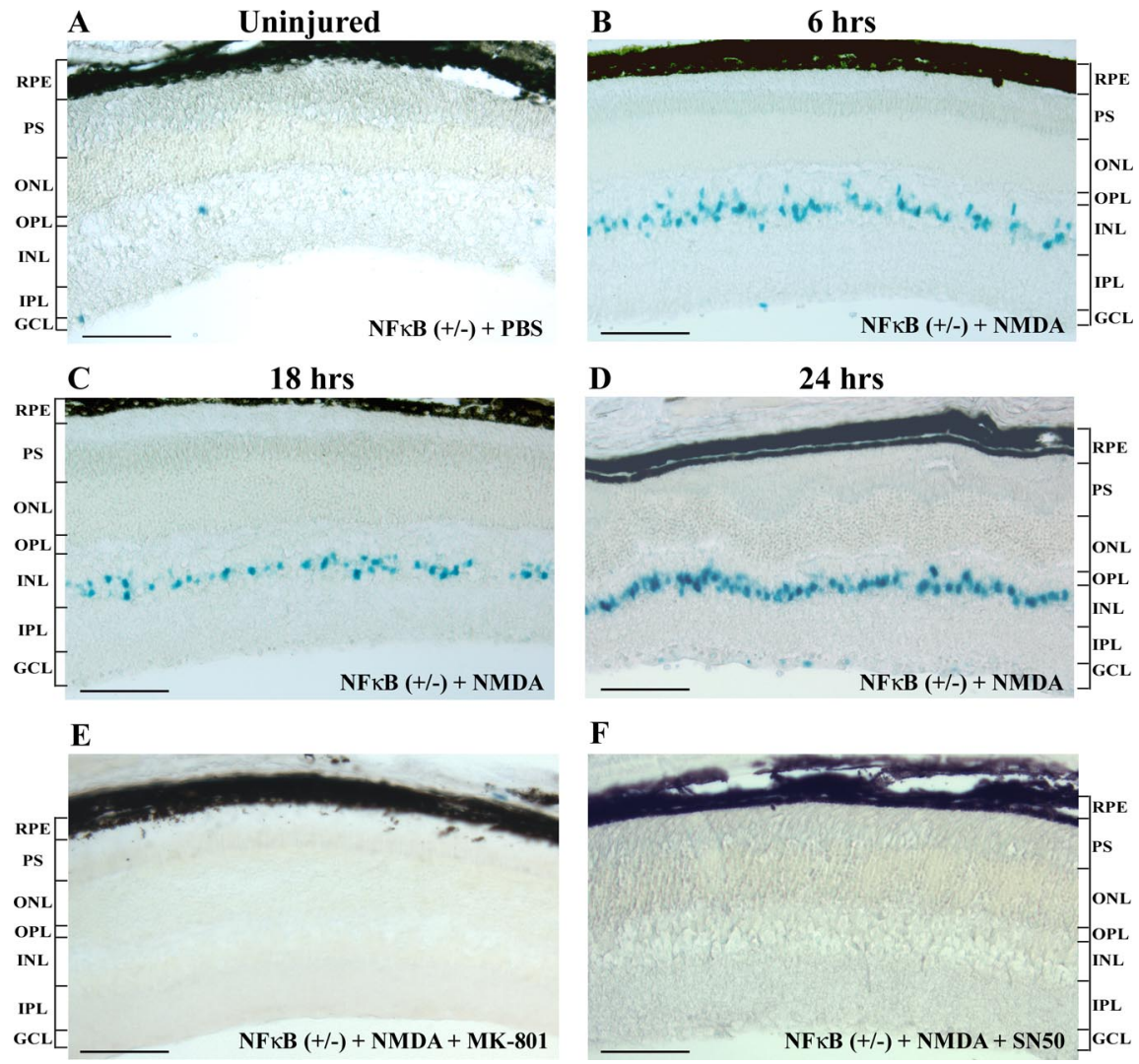

F

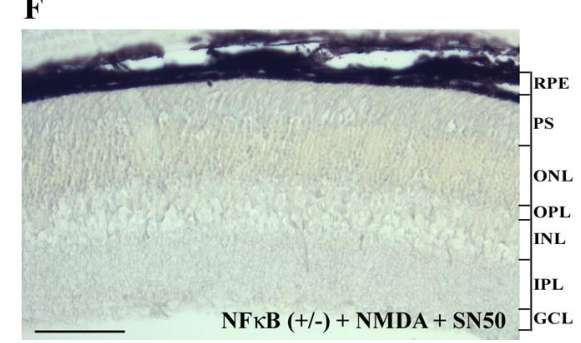

Figure 3. NF- $\kappa B$ is activated in the inner nuclear layer following exposure to NMDA. The cellular localization of NMDA-induced $\mathrm{NF}-\kappa B$ activity in the adult retina was examined in NF- $\kappa$ B reporter mice. $A-D$, Almost no NF- $\kappa B$ reporter activity was detected in the PBS-treated, uninjured retina $(n=3)(\boldsymbol{A})$, whereas retinas examined at $6 \mathrm{~h}(\boldsymbol{B}), 18 \mathrm{~h}(\boldsymbol{C})$, and $24 \mathrm{~h}(\boldsymbol{D})$ after NMDA injection showed a striking increase in $\beta$-gal activity in the inner nuclear layer ( $n=4-6 /$ group). $\boldsymbol{E}, \boldsymbol{F}$, The NF- $\kappa$ B transcriptional activity invoked by NMDA was completely blocked with the NMDA receptor antagonist, MK-801 $(n=4)(\boldsymbol{E})$, and with the NF- $\kappa$ B inhibitor SN50 $(\boldsymbol{F}, n=4)$. RPE, Retinal pigment epithelium; PS, photoreceptor segment; ONL, outer nuclear layer; OPL, outer plexiform layer; INL, inner nuclear layer; IPL, inner plexiform layer; GCL, ganglion cell layer. Scale bars, $100 \mu \mathrm{m}$.

NF- $\kappa \mathrm{B}$ transcriptional activity has been reported to promote proapoptotic or antiapoptotic responses following CNS injury (Maggirwar et al., 1998; Hamanoue et al., 1999; Schneider et al., 1999; Bhakar et al., 2002; Schwaninger et al., 2006), but the molecular basis for these divergent effects remains unknown. To determine whether NF- $\kappa$ B activity influenced NMDA-induced neuronal death in the retina, we asked whether SN50, a cell-permeable peptide that blocks nuclear translocation of NF- $\kappa \mathrm{B}$ subunits, altered levels of NMDA-induced cell loss. Intriguingly, coadministration of SN50 with NMDA sharply reduced the number of TUNEL ${ }^{+}$cells, both in the ganglion cell layer and inner nuclear layer (Fig. $2 A$ ). In contrast, SN50M, a mutant form of SN50 that does not block NF- $\kappa$ B nuclear translocation, had no effect on NMDA-induced TUNEL labeling.

Induction of canonical NF- $\kappa \mathrm{B}$ signaling requires activation of $\mathrm{I} \kappa \mathrm{B}$ kinase (IKK) 1 and IKK2, kinases that phosphorylate I $\kappa \mathrm{B}$ family members (Schmid and Birbach, 2008). IKK2 often plays an obligatory role in canonical NF- $\kappa \mathrm{B}$ signaling; thus, we asked whether PS1145, a small-molecule inhibitor of IKK2, altered retinal ganglion cell death induced by NMDA. Figure $2 B$ shows that PS1 145 elicited a remarkable inhibition of NMDA-induced retinal ganglion cell death, equivalent to that evoked by SN50 or by the noncompetitive NMDA receptor antagonist, MK801. Therefore, NF- $\kappa \mathrm{B}$ is strongly activated in the retina following NMDA exposure and inhibitors that block NF- $\kappa \mathrm{B}$ transcriptional activity, by different mechanisms, rescue neurons challenged with NMDA. We conclude that NF- $\kappa \mathrm{B}$ activation plays a crucial role in NMDA-induced loss of retinal neurons.
NMDA induces NF- $\kappa$ B activity in Müller glia but not in retinal neurons To determine the cellular localization of NMDA-induced NF- $\kappa$ B activity in the adult retina, we used a well-characterized reporter mouse in which NF- $\kappa$ B-responsive elements drive expression of nuclear $\beta$-gal (Bhakar et al., 2002). In the PBS-treated, uninjured retina, almost no NF- $\kappa$ B reporter activity was detected (Fig. $3 A$ ). In contrast, retinas examined at 6,18 , and $24 \mathrm{~h}$ after NMDA injection showed a striking increase in $\beta$-gal activity within the inner nuclear layer (Fig. $3 B-D$ ). The induction of NF- $\kappa \mathrm{B}$ in the retina invoked by NMDA was completely blocked by the NMDA receptor antagonist, MK-801 (Fig. $3 E$ ), and with the NF- $\kappa \mathrm{B}$ inhibitor SN50 (Fig. 3F). These results indicate that the $\beta$-gal activity detected in the inner nuclear layer reflects an NF- $\kappa$ B transcriptional response mediated through activation of NMDA receptors.

The inner nuclear layer of the retina consists of interneurons (amacrine, bipolar, and horizontal cells) and Müller glial cells. To determine which of these cell types exhibit NMDA-induced NF- $\kappa$ B activation, retina derived from NF- $\kappa \mathrm{B}$ reporter mice were stained using antibodies for $\beta$-gal and for retinal cell-type markers. After intravitreal injection of NMDA, $\beta$-gal-expressing cells were consistently positive for cellular retinaldehyde-binding protein (CRALBP), a specific Müller cell marker (Fig. $4 A-C$ ). In contrast, $\beta$-gal staining was never found in cells positive for markers of bipolar and amacrine cells, including protein kinase C (Fig. $4 D-F$ ) or calretinin (Fig. $4 G-I$ ), respectively. We conclude that Müller glia is the only cell type within the inner nuclear layer that undergoes NMDA-induced NF- $\kappa$ B activation.

NMDA exposure induced $\beta$-gal expression in a very small number of cells within the ganglion cell layer in the NF- $\kappa$ B reporter mice (Fig. $3 B-D)$. In addition to retinal ganglion cells, this region contains astrocytes, macrophages, and displaced amacrine cells. The few $\beta$-gal-labeled cells observed in this region were invariably positive for cell-specific markers of astrocytes (GFAP, Fig. $4 J-L$ ) or macrophages (MAC-1, Fig. $4 M-O$ ). $\beta$-gal staining was never observed in retinal ganglion cells retrogradely labeled with Fluorogold (Fig. $4 P-R$ ) or in calretinin-positive displaced amacrine cells (data not shown). These data demonstrate that NMDA induces NF- $\kappa$ B activity in Müller glia but not in retinal neurons. This finding led us to test the hypothesis that a Müller cell-derived factor, regulated by NF- $\kappa \mathrm{B}$, acts in a non-cell-autonomous manner to facilitate neuronal death following NMDA exposure.

\section{TNF $\boldsymbol{\alpha}$ produced by Müller cells promotes NMDA-dependent neuronal loss}

$\mathrm{TNF} \alpha$ transcription is strongly regulated by NF- $\kappa \mathrm{B}$ activity (Shakhov et al., 1990; Hiscott et al., 1993; Mori and Prager, 1996), and TNF $\alpha$ added exogenously can increase death of retinal neurons (Tezel and Wax, 2000; Nakazawa et al., 2006; Berger et al., 2008). We therefore tested whether Müller cell-derived TNF $\alpha$ acts as an endogenous factor that facilitates NMDA-dependent neuronal death in 
vivo. Figure $5 A$ shows that $\mathrm{TNF} \alpha$ protein was undetectable in the adult, intact retina, but its levels increased dramatically after NMDA exposure. The NMDA-induced increase in TNF $\alpha$ expression was completely blocked by the NF- $\kappa \mathrm{B}$ inhibitor SN50, indicating that activation of NF- $\kappa \mathrm{B}$ plays a central role in NMDA-dependent expression of this cytokine. Similarly, TNF $\alpha$ was not detected in the uninjured retina by immunocytochemistry (Fig. $5 B$ ) but was clearly visualized after NMDA injection in presumptive Müller cell bodies and processes in the inner retina (Fig. 5C). Moreover, NMDA-induced accumulation of $\mathrm{TNF} \alpha$ immunoreactivity was blocked by the NF- $\kappa \mathrm{B}$ inhibitor SN50 (Fig. $5 D)$. Colabeling experiments using the Müller cell-specific marker CRALBP confirmed that Müller cells selectively upregulate expression of TNF $\alpha$ in the presence of NMDA (Fig. 5E-G). We conclude that Müller glial cells are the main cellular source of TNF $\alpha$ production in the retina following NMDA exposure.

To test whether Müller cell-derived TNF $\alpha$ facilitates excitotoxic death of retinal neurons, we examined whether the extent of NMDA-induced retinal ganglion cell loss was attenuated in the absence of TNF $\alpha$. Our data show striking survival of retinal ganglion cells in TNF $\alpha$ knock-out mice at $6 \mathrm{~h}$ after NMDA exposure: $76 \%$ of these neurons remained alive compared with only $42 \%$ in wild-type littermate controls ( $p<$ 0.001 ) (Fig. $5 H$ ). Although the total number of retinal ganglion cells in adult $\mathrm{TNF} \alpha$ null mice treated only with vehicle was similar to that in wild-type mice (Fig. $5 H$ ), it is conceivable that increased neuronal survival following NMDA injection in TNF $\alpha$ null mice reflects a chronic effect of TNF $\alpha$ deprivation. As an alternative approach, we blocked $\mathrm{TNF} \alpha$ action in the retina using Etanercept, a soluble Fc fusion protein that contains the extracellular ligand-binding domain of TNF $\alpha$ receptor (TNFR)2 that is used clinically for blockade of TNF $\alpha$ in humans with rheumatoid arthritis or psoriasis (Fantuzzi et al., 2008; Lyudmila, 2008). Figure $5 H$ shows that Etanercept (Immunex), but not control Fc, protected retinal ganglion cells from NMDA-induced death. Etanercept protected $75 \%$ of these neurons from NMDAinduced death compared with only $\sim 45 \%$ in Fc-treated or vehicle-treated controls $(p<$ $0.001)$. We conclude that $\mathrm{TNF} \alpha$ derived from Müller glia acts in a non-cell-autonomous manner to promote NMDA-dependent neuronal death in the retina.

Endogenous TNF $\alpha$ exacerbates excitotoxicity by increasing neuronal $\mathrm{Ca}^{2+}$-permeable AMPARs

We then asked what mechanisms are used by endogenous TNF $\alpha$ released from Müller cells to exacerbate NMDA-dependent neu$12.5 \mu \mathrm{m}$.
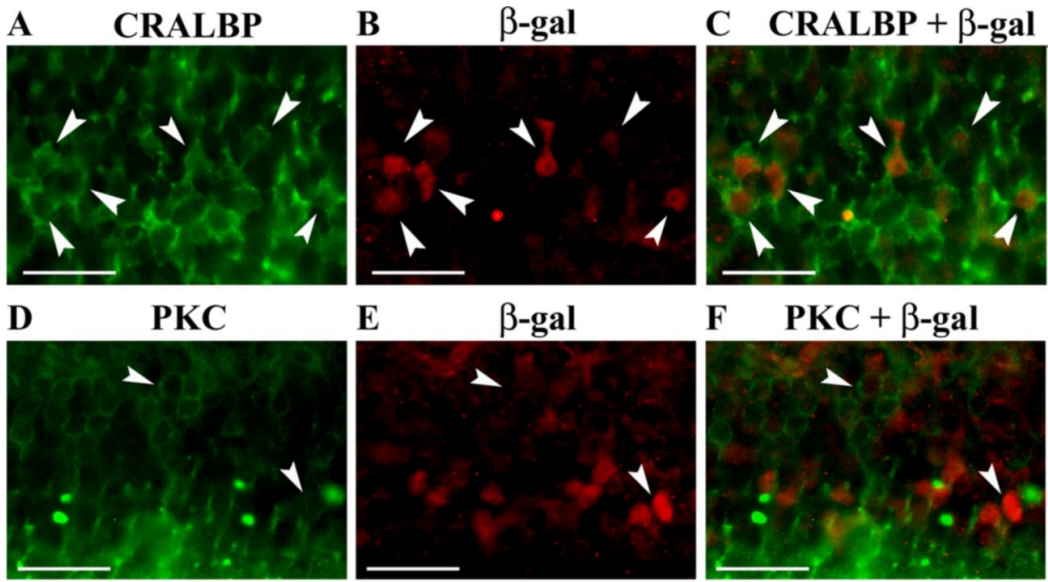

F $\quad \mathbf{P K C}+\beta$-gal
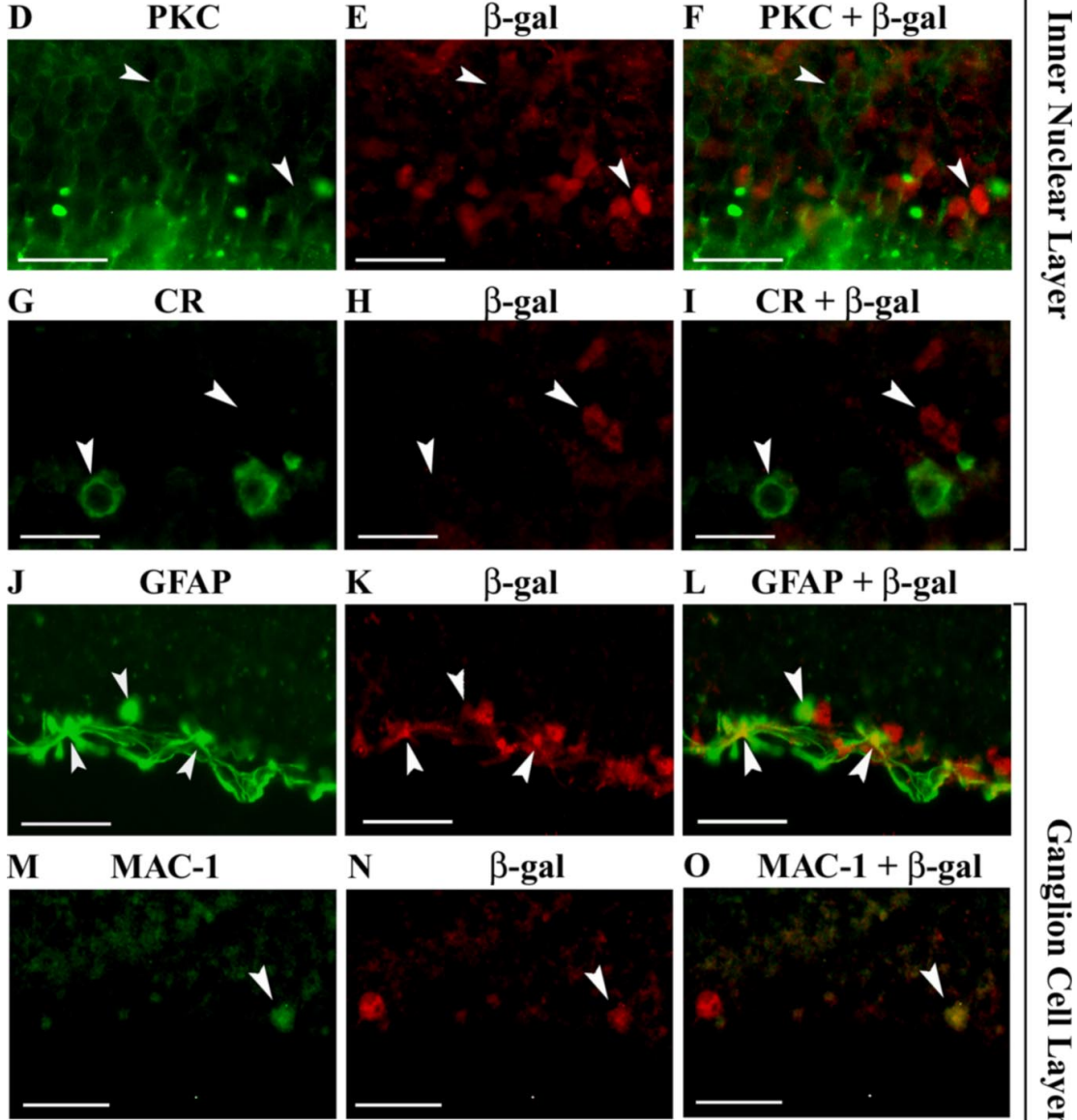

L $\quad$ GFAP + $\beta$-gal
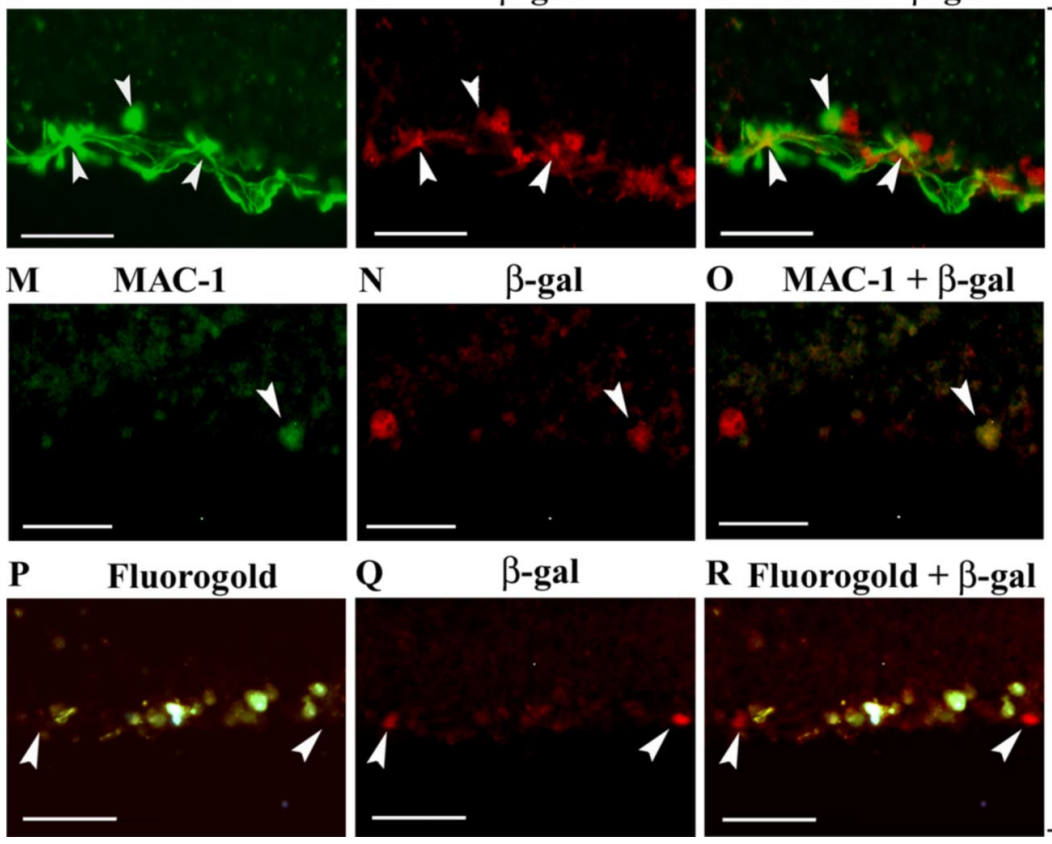

Figure 4. NMDA induces NF- $\kappa$ B activity in Müller glia but not in retinal neurons. Double immunohistochemistry using a $\beta$-gal $\mathrm{Ab}$ and specific markers for each retinal cell type was carried out on retinal sections at $24 \mathrm{~h}$ after NMDA injection. In the inner nuclear layer, cells positive for CRALBP, a Müller cell-specific marker, were always positive for $\beta$-gal ( $\boldsymbol{A}-\boldsymbol{C})$. No colocalization was found between $\beta$-gal and bipolar cell markers, including protein kinase $C$ (PKC) (D-F, arrows), or amacrine cell markers, including calretinin (CR) ( $G-I$, arrows). The few $\beta$-gal-labeled cells observed in the ganglion cell layer were invariably positive for markers of astrocytes (GFAP) $(J-L)$ or macrophages/microglia (MAC-1) $(M-0)$. $\beta$-gal staining was never observed in retinal ganglion cells retrogradely labeled with Fluorogold $(\boldsymbol{P}-\boldsymbol{R})$ or in displaced amacrine cells (data not shown). All scale bars, $50 \mu \mathrm{m}$, except $\mathbf{G}-\boldsymbol{I}$,

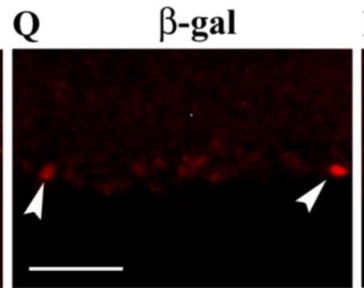

R Fluorogold $+\beta$-gal

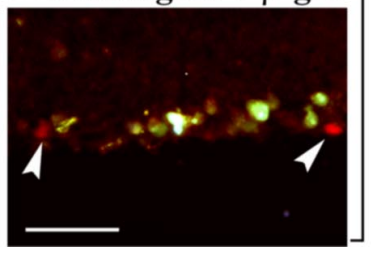

ronal loss in the retina. Engagement of the TNFR1 receptor can activate caspase- 8 to induce apoptosis (Thorburn, 2004). We therefore tested whether inhibition of caspase- 8 activation reduced NMDA-mediated excitotoxicity. Blockade of caspase 8 activity using z-IETD-fmk, a potent caspase 8 inhibitor previously shown to effectively inhibit caspase 8 in vivo at the concentrations used here (Weishaupt et al., 2003), had no effect on NMDA- 

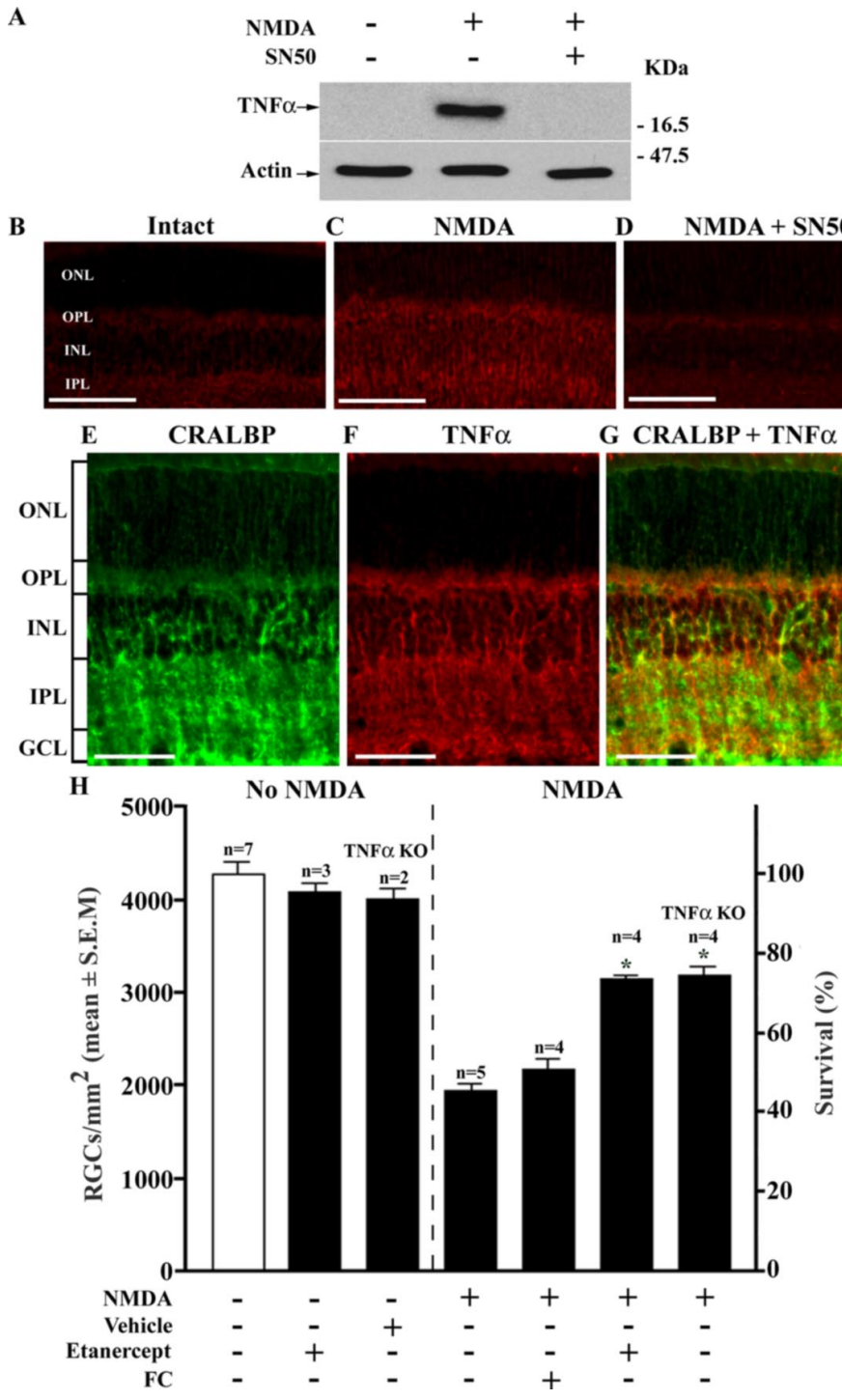

Figure 5. TNF $\alpha$ produced by Müller glia promotes NMDA-dependent neuronal loss. $\boldsymbol{A}$, Western blot analysis of retinal homogenates show that TNF $\alpha$ protein levels were low in the uninjured retina and increased following NMDA intraocular injection. NMDA-induced increase in TNF $\alpha$ protein was blocked with the NF- $\kappa$ B inhibitor SN50. B, C, By immunohistochemistry, TNF $\alpha$ was not detected in the uninjured retina $(\boldsymbol{B})$ but was clearly visualized after NMDA injection $(\boldsymbol{C})$ in presumptive Müller cell bodies and processes in the inner retina. D, NMDA-induced TNF $\alpha$ immunoreactivity was blocked by the NF- $\kappa$ B inhibitor SN50. E-G, Colabeling experiments using the Müller cell-specific marker CRALBP confirmed that TNF $\alpha$ is upregulated in Müller glia in the presence of NMDA. Scale bars, $100 \mu \mathrm{m}(\boldsymbol{B}-\boldsymbol{D}), 50 \mu \mathrm{m}(\boldsymbol{E}-\boldsymbol{G})$. $\boldsymbol{H}$, Striking neuroprotection after NMDA exposure was observed in TNF $\alpha$ knock-out mice or in the presence of the TNF $\alpha$ blocker Etanercept, whereas no survival was observed in wild-type littermate or Fc-treated controls (ANOVA; $\left.{ }^{*} p<0.001\right)$. Values are expressed as retinal ganglion cell densities (RGCs/mm ${ }^{2}$; mean \pm SEM) and are compared with intact retinas ( $100 \%$ survival, $\square$ ).

induced retinal ganglion cell death (supplemental Fig. 2, available at www.jneurosci.org as supplemental material). z-IETD-fmk, by itself, was not toxic and did not promote retinal ganglion cell death. These findings indicate that TNF $\alpha$-dependent neuronal loss occurs via an alternative pathway.

Exogenous TNF $\alpha$ has been shown to induce selective cell surface expression of $\mathrm{Ca}^{2+}$-permeable AMPARs (Beattie et al., 2002; Ogoshi et al., 2005; Stellwagen et al., 2005), and their expression has been correlated with enhanced neuronal death in models of ischemia and excitotoxicity (Hermann et al., 2001; Noh et al., 2005; Ferguson et al., 2008; Leonoudakis et al., 2008). We tested the hypothesis that TNF $\alpha$ produced by Müller glia increases cell surface $\mathrm{Ca}^{2+}$-permeable AMPARs on retinal neurons, thus rendering them more susceptible to excitotoxicity. $\mathrm{Ca}^{2+}$-permeable
AMPARs transport divalent cations such as cobalt $\left(\mathrm{Co}^{2+}\right)$; therefore, we used an in situ $\mathrm{Co}^{2+}$ staining technique to identify retinal cells that express $\mathrm{Ca}^{2+}$-permeable AMPARs. In the absence of NMDA, $\mathrm{Co}^{2+}$ accumulation was restricted to cells in the inner nuclear and ganglion cell layers (Fig. $6 \mathrm{~A}$ ) previously identified as horizontal and AII amacrine cells (Osswald et al., 2007) as well as ganglion cells (Zhang et al., 1995). Following NMDA exposure, both amacrine and retinal ganglion cells accumulated $\mathrm{Co}^{2+}$, indicating that $\mathrm{Ca}^{2+}$ permeability in these cells was markedly enhanced when the retina was challenged with NMDA (Fig. 6B). To test whether $\mathrm{TNF} \alpha$ was required for NMDA-induced increase of $\mathrm{Ca}^{2+}$-permeable AMPARs on retinal neurons, NMDA was coadministered with the TNF $\alpha$ antagonist Etanercept. Figure $6 C$ shows that Etanercept effectively diminished the NMDA-induced $\mathrm{Co}^{2+}$ uptake.

To confirm that increased $\mathrm{Co}^{2+}$ accumulation in retinal neurons occurs via $\mathrm{Ca}^{2+}$-permeable AMPARs and not other glutamate receptors, retinas were incubated with GYKI, a noncompetitive AMPAR-selective antagonist, and IEM, a channel blocker selective for $\mathrm{Ca}^{2+}$. permeable non-NMDA receptors (i.e., AMPA and kainate receptors). Figure 6, $D$ and $E$, shows that NMDA-induced $\mathrm{Co}^{2+}$ accumulation in these neurons was blocked with IEM and GYKI, indicating that NMDA-induced $\mathrm{Co}^{2+}$ accumulation is due to increased flux of divalent cations exclusively through AMPARs. Finally, we tested whether TNF $\alpha$-mediated increase in neuronal $\mathrm{Ca}^{2+}$ permeability influenced neuronal death following NMDA exposure. Figure $6 F$ shows that retinal ganglion cells were markedly protected from NMDA-induced death in the presence of either IEM (63\% survival) or GYKI (76\% survival) with respect to control retinas (ANOVA; $p<0.001$ ). The neuronal survival afforded by AMPAR blockers was similar to that observed in TNF $\alpha$ null mice or following treatment with the $\mathrm{TNF} \alpha$ antagonist Etanercept (Fig. $5 H$ ). We conclude that Müller cell-derived TNF $\alpha$ plays a crucial role in the NMDA-dependent elaboration of $\mathrm{Ca}^{2+}$ permeable AMPARs and, ultimately, excitotoxic death of retinal neurons.

\section{Discussion}

This study reports four major findings. First, NMDA exposure causes induction of NF- $\kappa \mathrm{B}$ activity in Müller glia, but not neurons, in the adult retina. Second, the death of amacrine and retinal ganglion cells induced by NMDA is sharply attenuated when Müller cell NF- $\kappa$ B activation is blocked. Third, TNF $\alpha$ is the target of NF- $\kappa$ B activity in Müller cells and is required for NMDAinduced loss of retinal neurons. Fourth, increased levels of $\mathrm{Ca}^{2+}$ 
permeable AMPARs evoked by Müller cell-derived TNF $\alpha$ is a crucial mechanism that renders retinal neurons susceptible to excitotoxic injury.

The accessibility and defined cellular architecture of the retina, together with the exquisite sensitivity of retinal neurons to NMDA, make it an ideal system to elucidate the contribution of NF- $\kappa \mathrm{B}$ to excitotoxicity. We showed that NF- $\kappa \mathrm{B}$ is activated in Müller glia following NMDA exposure. The effect of NMDA on NF- $\kappa \mathrm{B}$ activation in Müller glia was blocked by MK-801, confirming that NMDA receptors are involved in this response. NMDA receptors have been described on dissociated Müller cells from human (Puro et al., 1996) and chick retinas (Lamas et al., 2005), and in situ hybridization studies have demonstrated expression of NMDA receptors in the rat inner plexiform layer where Müller cells reside (Brandstätter et al., 1994; Hartveit et al., 1994; Fletcher et al., 2000). The functional properties of glial and neuronal NMDA receptors are thought to be different (Lamas et al., 2005); it is thus possible that NMDA receptors with different oligomeric structures differ in their ability to activate NF$\kappa \mathrm{B}$. Alternatively, NMDA-dependent NF- $\kappa$ B activation in retinal glia may be indirect and results from a stimulating factor produced by neurons. Candidates for this effect are neuronal release of ATP and activation of glial $\mathrm{P} 2 \mathrm{Y}$ receptors (Metea and Newman, 2006) and glutamate, which is released in high amounts by stressed neurons (Fujimoto et al., 2004). Regarding the latter possibility, previous studies have shown that occupancy of metabotropic glutamate receptors on glia can induce $\mathrm{NF}-\kappa \mathrm{B}$ activation (Caccamo et al., 2005a,b; Kaushal and Schlichter, 2008; Sitcheran et al., 2008).

Blockade of NF- $\kappa$ B activity in Müller cells dramatically reduced amacrine and retinal ganglion cell death, indicating that a Müller cell-derived factor plays a crucial role in NMDA-induced excitotoxicity. We focused on TNF $\alpha$ as a major effector in this pathway because the $\mathrm{TNF} \alpha$ gene is tightly regulated by NF$\kappa \mathrm{B}$, and previous studies have indicated that TNF $\alpha$ can facilitate excitotoxic damage (Chao and $\mathrm{Hu}$, 1994; Hermann et al., 2001; Bernardino et al., 2005; Noh et al., 2005; Ferguson et al., 2008; Kaushal and Schlichter, 2008; Leonoudakis et al., 2008). We showed that TNF $\alpha$ in Müller glia was dramatically increased by NMDA exposure, and our loss of function experiments confirmed that TNF $\alpha$ plays an obligatory role in the loss of retinal neurons induced by NMDA. These results are consistent with a previous study showing that retinal ganglion cells lacking TNFR1 are protected following optic nerve crush (Tezel et al., 2004). Interestingly, TNF $\alpha$ and
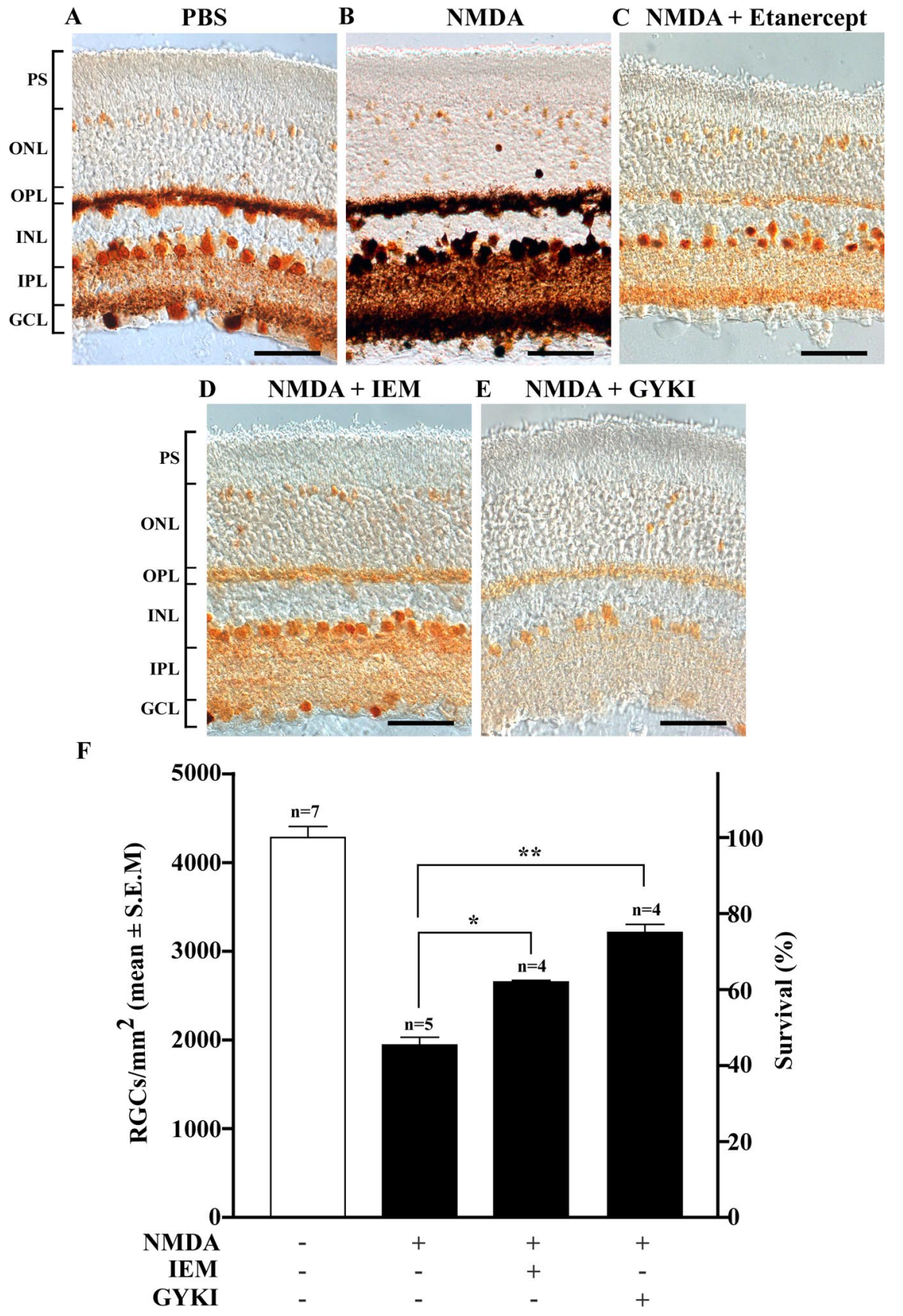

Figure 6. TNF $\alpha$ exacerbates excitotoxicity by increasing neuronal $\mathrm{Ca}^{2+}$-permeable AMPARs. $\boldsymbol{A}$, In the absence of NMDA, $\mathrm{CO}^{2+}$ accumulation was restricted to a few cells in the inner nuclear and ganglion cell layers. $\boldsymbol{B}$, Following NMDA exposure, both amacrine and retinal ganglion cells accumulated $\mathrm{C}^{2+}$, indicating that $\mathrm{Ca}^{2+}$ permeability in these cells was markedly enhanced. $\boldsymbol{C}-\boldsymbol{E}$, The TNF $\alpha$ antagonist Etanercept ( $\boldsymbol{C}$, as well as the AMPAR blockers IEM-1460 (D) and GYKI $(\boldsymbol{E})$ effectively reduced NMDAinduced $\mathrm{Co}^{2+}$ uptake. Scale bars, $40 \mu \mathrm{m}$. $\boldsymbol{F}$, Retinal ganglion cells were protected from NMDA-induced death in the presence of either IEM-1460 or GYKI, with respect to control retinas (ANOVA; ${ }^{*} p<0.05 ;{ }^{* *} p<0.001$ ). Values are expressed as retinal ganglion cell densities (RGCs/mm²; mean $\pm \mathrm{SEM}$ ) and are compared with intact retinas ( $100 \%$ survival, $\square$ ).

TNFR1 have been shown to be upregulated in human donor eyes with glaucoma (Yan et al., 2000; Yuan and Neufeld, 2000; Tezel et al., 2001), diabetic retinopathy, and age-related macular degeneration (Armstrong et al., 1998; Oh et al., 1999); in addition, TNF $\alpha$ gene polymorphisms have been found in patients with primary open angle glaucoma (Lin et al., 2003; Funayama et al., 2004), supporting a crucial role for TNF $\alpha$ in ocular diseases.

How does NF- $\kappa$ B-mediated production of TNF $\alpha$ by Müller glia kills retinal neurons? Ligand binding to TNFR1 triggers ap- 
optosis by induction of caspase- 8 activation, which in turn activates caspase-3 and promotes cell death (Boldin et al., 1996; Hsu et al., 1996). Previous studies have shown that TNF $\alpha$ released from microglia can kill primary cortical neurons via a caspase-8dependent mechanism (Velier et al., 1999; Kaushal and Schlichter, 2008); however, we found that caspase- 8 inhibition had no effect on NMDA-induced apoptosis of retinal neurons in vivo. Nevertheless, apoptosis is still a major cell death mechanism in this model based on the widespread TUNEL labeling observed by us and others (Manabe and Lipton, 2003; Nakazawa et al., 2005) and is likely to involve induction of the intrinsic mitochondrial pathway and activation of caspase- 3 .

Our data support an alternative mechanism that invokes TNF $\alpha$-mediated increase of $\mathrm{Ca}^{2+}$-permeable AMPARs on neuronal cell surfaces. A series of elegant in vitro studies demonstrated that glia-derived TNF $\alpha$ selectively stimulates cell surface insertion of $\mathrm{Ca}^{2+}$-permeable AMPARs, while simultaneously decreasing surface $\mathrm{GABA}_{\mathrm{A}}$ receptors, a process required for rapid control of synaptic strength at excitatory synapses (Beattie et al., 2002; Stellwagen et al., 2005; Stellwagen and Malenka, 2006). $\mathrm{Ca}^{2+}$-permeable AMPARs have been proposed as mediators of excitotoxic cell death (Kwak and Weiss, 2006; Liu and Zukin, 2007). Recent studies have shown that exogenous TNF $\alpha$ may contribute to excitotoxicity by increasing cell surface levels of $\mathrm{Ca}^{2+}$-permeable AMPARs in primary hippocampal neurons and spinal cord (Ferguson et al., 2008; Leonoudakis et al., 2008), but the cellular source and mechanisms that lead to $\mathrm{TNF} \alpha$ production were not addressed in these studies. We provide the first in vivo evidence that Müller glia-derived TNF $\alpha$ exacerbates excitotoxic damage by increasing surface levels of $\mathrm{Ca}^{2+}$-permeable AMPARs in retinal neurons.

Our data support a model in which non-cell-autonomous signaling events play a major role in NMDA-triggered excitotoxicity in the retina. We demonstrate that NMDA-dependent activation of NF- $\kappa \mathrm{B}$ in Müller glial cells induces production of endogenous glia-derived TNF $\alpha$, which in turn renders retinal neurons highly sensitive to excitotoxicity by increasing their surface levels of $\mathrm{Ca}^{2+}$-permeable AMPARs. Our loss-of-function experiments show that this non-cell-autonomous mechanism accounts for $>60 \%$ of the NMDA-induced neuronal loss in the retina. Given the prevalence of NMDA receptors on retinal neurons (Zhang and Diamond, 2006), direct action of NMDA may play a modest, yet tangible, role in excitotoxicity in this system. However, our findings are a departure from the traditional paradigm of excitotoxic damage in which the death of neurons was entirely attributed to excessive $\mathrm{Ca}^{2+}$ influx via neuronal NMDA receptors. Instead, our data indicate that glial regulation of neuronal AMPAR distribution via TNF $\alpha$ is a central requirement for neuronal loss in retinal excitotoxicity.

There is strong evidence that glutamate, the endogenous neurotransmitter involved in excitotoxicity, increases intracellular $\mathrm{Ca}^{2+}$ in retinal ganglion cells primarily via NMDA receptors (Hartwick et al., 2008) raising the question: how do AMPARs mediate neuronal death? Interestingly, AMPARs are highly permeable to $\mathrm{Zn}^{2+}$, whereas NMDA receptors are blocked by this cation. $\mathrm{Zn}^{2+}$, known to accumulate in hippocampal neurons following ischemia and before the onset of cell death (Koh et al., 1996; Lee et al., 2003), is extremely toxic for neurons (Sensi et al., 1999, 2003; Jiang et al., 2001; Kim and Koh, 2002). The elucidation of the precise role of $\mathrm{Zn}^{2+}$ in retinal ganglion cell death will be an interesting topic for future studies.

Our results are unexpected because Müller cells have been traditionally attributed a neuroprotective role under physiologi- cal conditions (Bringmann et al., 2006). Indeed, one of the normal functions of Müller cells is the modulation of synaptic transmission and neuronal excitability in the mammalian retina (Newman, 2004). It is possible that the injury-induced effects reported here represent the end of a physiological continuum; it will be interesting to determine if the low levels of TNF $\alpha$ produced by Müller cells in the uninjured, adult retina alters synaptic transmission through AMPAR-dependent mechanisms.

The failure of NMDA receptor antagonists in clinical trials (Lee et al., 1999; Ikonomidou and Turski, 2002; Kemp and McKernan, 2002; Kalia et al., 2008) presupposes that other molecular mechanisms play a critical role following the initial excitotoxic insult. Our study provides new insight into these events in vivo by demonstrating a new role for NF- $\kappa \mathrm{B}$ in the injured CNS. Furthermore, we identify TNF $\alpha$ as a key glial-to-neuron signal that exacerbates excitotoxicity through modulation of $\mathrm{Ca}^{2+}$-permeable AMPARs. The precise delineation of the molecular events that occur in glia versus those in neurons, as shown here, should be useful for the design of novel therapeutic interventions applicable to neurodegenerative diseases and ischemia.

\section{References}

Armstrong D, Augustin AJ, Spengler R, Al-Jada A, Nickola T, Grus F, Koch F (1998) Detection of vascular endothelial growth factor and tumor necrosis factor $\alpha$ in epiretinal membranes of proliferative diabetic retinopathy, proliferative vitreoretinopathy and macular pucker. Ophthalmologica 212:410-414.

Barone FC, Feuerstein GZ (1999) Inflammatory mediators and stroke, new opportunities for novel therapeutics. J Cereb Blood Flow Metab 19:819-834.

Beattie EC, Stellwagen D, Morishita W, Bresnahan JC, Ha BK, Von Zastrow M, Beattie MS, Malenka RC (2002) Control of synaptic strength by glial TNF $\alpha$. Science 295:2282-2285.

Berger S, Savitz SI, Nijhawan S, Singh M, David J, Rosenbaum PS, Rosenbaum DM (2008) Deleterious role of TNF- $\alpha$ in retinal ischemia-reperfusion injury. Invest Ophthalmol Vis Sci 49:3605-3610.

Berkelaar M, Clarke DB, Wang YC, Bray GM, Aguayo AJ (1994) Axotomy results in delayed death and apoptosis of retinal ganglion cells in adult rats. J Neurosci 14:4368-4374

Bernardino L, Xapelli S, Silva AP, Jakobsen B, Poulsen FR, Oliveira CR, Vezzani A, Malva JO, Zimmer J (2005) Modulator effects of interleukin $1 \beta$ and tumor necrosis factor $\alpha$ on AMPA-induced excitotoxicity in mouse organotypic hippocampal slice cultures. J Neurosci 25:6734-6744.

Bhakar AL, Tannis LL, Zeindler C, Russo MP, Jobin C, Park DS, MacPherson $\mathrm{S}$, Barker PA (2002) Constitutive nuclear factor $\kappa \mathrm{B}$ activity is required for central neuron survival. J Neurosci 22:8466-8475.

Boldin MP, Goncharov TM, Goltsev YV, Wallach D (1996) Involvement of $\mathrm{MACH}$, a novel MORT1/FADD-interacting protease, in Fas/APO-1- and TNF receptor-induced cell death. Cell 85:803-815.

Brandstätter JH, Hartveit E, Sassoè-Pognetto M, Wässle H (1994) Expression of NMDA and high-affinity kainate receptor subunit mRNAs in the adult rat retina. Eur J Neurosci 6:1100-1112.

Bringmann A, Pannicke T, Grosche J, Francke M, Wiedemann P, Skatchkov SN, Osborne NN, Reichenbach A (2006) Muller cells in the healthy and diseased retina. Prog Retin Eye Res 25:397-424.

Caccamo D, Campisi A, Marini H, Adamo EB, Li Volti G, Squadrito F, Ientile $\mathrm{R}$ (2005a) Glutamate promotes $\mathrm{NF}-\kappa \mathrm{B}$ pathway in primary astrocytes: protective effects of IRFI 016, a synthetic vitamin E analogue. Exp Neurol 193:377-383.

Caccamo D, Campisi A, Currò M, Bramanti V, Tringali M, Li Volti G, Vanella A, Ientile R (2005b) Antioxidant treatment inhibited glutamate-evoked NF- $\kappa \mathrm{B}$ activation in primary astroglial cell cultures. Neurotoxicology 26:915-921.

Casson RJ (2006) Possible role of excitotoxicity in the pathogenesis of glaucoma. Clin Experiment Ophthalmol 34:54-63.

Chao CC, Hu S (1994) Tumor necrosis factor $\alpha$ potentiates glutamate neurotoxicity in human fetal brain cell cultures. Dev Neurosci 16:172-179.

Cheng L, Sapieha P, Kittlerova P, Hauswirth WW, Di Polo A (2002) TrkB gene transfer protects retinal ganglion cells from axotomy-induced death in vivo. J Neurosci 22:3977-3986. 
Fantuzzi F, Del Giglio M, Gisondi P, Girolomoni G (2008) Targeting tumor necrosis factor $\alpha$ in psoriasis and psoriatic arthritis. Expert Opin Ther Targets 12:1085-1096.

Ferguson AR, Christensen RN, Gensel JC, Miller BA, Sun F, Beattie EC, Bresnahan JC, Beattie MS (2008) Cell Death after spinal cord injury is exacerbated by rapid TNF $\alpha$-induced trafficking of GluR2-lacking AMPARs to the plasma membrane. J Neurosci 28:11391-11400.

Fischer D, Heiduschka P, Thanos S (2001) Lens-injury-stimulated axonal regeneration throughout the optic pathway of adult rats. Exp Neurol 172:257-272.

Fletcher EL, Hack I, Brandstätter JH, Wässle H (2000) Synaptic localization of NMDA receptor subunits in the rat retina. J Comp Neurol 420:98-112.

Fujimoto S, Katsuki H, Kume T, Kaneko S, Akaike A (2004) Mechanisms of oxygen glucose deprivation-induced glutamate release from cerebrocortical slice cultures. Neurosci Res 50:179-187.

Funayama T, Ishikawa K, Ohtake Y, Tanino T, Kurosaka D, Kimura I, Suzuki K, Ideta H, Nakamoto K, Yasuda N, Fujimaki T, Murakami A, Asaoka R, Hotta Y, Tanihara H, Kanamoto T, Mishima H, Fukuchi T, Abe H, Iwata $\mathrm{T}$, et al. (2004) Variants in optineurin gene and their association with tumor necrosis factor $\alpha$ polymorphisms in Japanese patients with glaucoma. Invest Ophthalmol Vis Sci 45:4359-4367.

Gavrieli Y, Sherman Y, Ben-Sasson SA (1992) Identification of programmed cell death in situ via specific labeling of nuclear DNA fragmentation. J Cell Biol 119:493-501.

Hamanoue M, Middleton G, Wyatt S, Jaffray E, Hay RT, Davies AM (1999) p75-Mediated NF- $\kappa$ B activation enhances the survival response of developing sensory neurons to nerve growth factor. Mol Cell Neurosci $14: 28-40$.

Hare W, WoldeMussie E, Lai R, Ton H, Ruiz G, Feldmann B, Wijono M, Chun T, Wheeler L (2001) Efficacy and safety of memantine, an NMDA-type open-channel blocker, for reduction of retinal injury associated with experimental glaucoma in rat and monkey. Surv Ophthalmol 45:S284-S289.

Hare WA, WoldeMussie E, Lai RK, Ton H, Ruiz G, Chun T, Wheeler L (2004) Efficacy and safety of memantine treatment for reduction of changes associated with experimental glaucoma in monkey, I: Functional measures. Invest Ophthalmol Vis Sci 45:2625-2639.

Hartveit E, Brandstätter JH, Sassoè-Pognetto M, Laurie DJ, Seeburg PH, Wässle H (1994) Localization and developmental expression of the NMDA receptor subunit NR2A in the mammalian retina. J Comp Neurol 348:570-582.

Hartwick ATE, Hamilton CM, Baldridge WH (2008) Glutamatergic calcium dynamics and deregulation of rat retinal ganglion cells. J Physiol 586:3425-3446.

Hermann GE, Rogers RC, Bresnahan JC, Beattie MS (2001) Tumor necrosis factor $\alpha$ induces cFOS and strongly potentiates glutamate-mediated cell death in the rat spinal cord. Neurobiol Dis 8:590-599.

Hiscott J, Marois J, Garoufalis J, D’Addario M, Roulston A, Kwan I, Pepin N, Lacoste J, Nguyen H, Bensi G (1993) Characterization of a functional $\mathrm{NF}-\kappa \mathrm{B}$ site in the human interleukin $1 \beta$ promoter: evidence for a positive autoregulatory loop. Mol Cell Biol 13:6231-6240.

Hoffmann A, Baltimore D (2006) Circuitry of nuclear factor $\kappa \mathrm{B}$ signaling. Immunol Rev 210:171-186.

Hsu H, Shu HB, Pan MG, Goeddel DV (1996) TRADD-TRAF2 and TRADD-FADD interactions define two distinct TNF receptor 1 signal transduction pathways. Cell 84:299-308.

Ikonomidou C, Turski L (2002) Why did NMDA receptor antagonists fail clinical trials for stroke and traumatic brain injury? Lancet Neurol 1:383-386.

Ito Y, Shimazawa M, Inokuchi Y, Fukumitsu H, Furukawa S, Araie M, Hara H (2008) Degenerative alterations in the visual pathway after NMDAinduced retinal damage in mice. Brain Res 1212:89-101.

Jeon GS, Park SK, Park SW, Kim DW, Chung CK, Cho SS (2008) Glial expression of interleukin-18 and its receptor after excitotoxic damage in the mouse hippocampus. Neurochem Res 33:179-184.

Jiang D, Sullivan PG, Sensi SL, Steward O, Weiss JH (2001) $\mathrm{Zn}^{2+}$ induces permeability transition pore opening and release of proapoptotic peptides from neuronal mitochondria. J Biol Chem 276:47524-47529.

Kacza J, Seeger J (1997) Transcellular labelling of activated retinal microglia following transection of the optic nerve. Inflamm Res 46:430-433.

Kalia LV, Kalia SK, Salter MW (2008) NMDA receptors in clinical neurology: excitatory times ahead. Lancet Neurol 7:742-755.
Kaushal V, Schlichter LC (2008) Mechanisms of microglia-mediated neurotoxicity in a new model of the stroke penumbra. J Neurosci 28:2221-2230.

Kemp JA, McKernan RM (2002) NMDA receptor pathways as drug targets. Nat Neurosci [Suppl] 5:1039-1042.

Kikuchi M, Kashii S, Honda Y, Ujihara H, Sasa M, Tamura Y, Akaike A (1995) Protective action of zinc against glutamate neurotoxicity in cultured retinal neurons. Invest Ophthalmol Vis Sci 36:2048-2053.

Kim YH, Koh JY (2002) The role of NADPH oxidase and neuronal nitric oxide synthase in zinc-induced poly(ADP-ribose) polymerase activation and cell death in cortical culture. Exp Neurol 177:407-418.

Koh J, Suh S, Gwag B, He Y, Hsu C, Choi D (1996) The role of zinc in selective neuronal death after transient global cerebral ischemia. Science 272:1013-1016.

Kwak S, Weiss JH (2006) Calcium-permeable AMPA channels in neurodegenerative disease and ischemia. Curr Opin Neurobiol 16:281-287.

Lamas M, Lee-Rivera I, López-Colomé AM (2005) Cell-specific expression of $N$-methyl-D-aspartate receptor subunits in Müller glia and neurons from the chick retina. Invest Ophthalmol Vis Sci 46:3570-3577.

Lee JM, Zipfel GJ, Choi DW (1999) The changing landscape of ischaemic brain injury mechanisms. Nature [Suppl] 399:A7-A14.

Lee JY, Kim JH, Palmiter RD, Koh JY (2003) Zinc released from metallothionein-iii may contribute to hippocampal CA1 and thalamic neuronal death following acute brain injury. Exp Neurol 184:337-347.

Leon S, Yin Y, Nguyen J, Irwin N, Benowitz LI (2000) Lens injury stimulates axon regeneration in the mature rat optic nerve. $J$ Neurosci 20:4615-4626.

Leonoudakis D, Zhao P, Beattie EC (2008) Rapid tumor necrosis factor $\alpha$-induced exocytosis of glutamate receptor 2-lacking AMPA receptors to extrasynaptic plasma membrane potentiates excitotoxicity. J Neurosci 28:2119-2130.

Lin HJ, Tsai FJ, Chen WC, Shi YR, Hsu Y, Tsai SW (2003) Association of tumour necrosis factor $\alpha$-308 gene polymorphism with primary openangle glaucoma in Chinese. Eye 17:31-34.

Liu SJ, Zukin RS (2007) $\mathrm{Ca}^{2+}$-permeable AMPA receptors in synaptic plasticity and neuronal death. Trends Neurosci 30:126-134.

Lyudmila S (2008) Approaches to the treatment of early rheumatoid arthritis with disease-modifying antirheumatic drugs. Brit J Clin Pharmacol 66:173-178.

Maggirwar SB, Sarmiere PD, Dewhurst S, Freeman RS (1998) Nerve growth factor-dependent activation of NF- $\kappa \mathrm{B}$ contributes to survival of sympathetic neurons. J Neurosci 18:10356-10365.

Manabe S, Lipton SA (2003) Divergent NMDA signals leading to proapoptotic and antiapoptotic pathways in the rat retina. Invest Ophthalmol Vis Sci 44:385-392.

Mansour-Robaey S, Clarke DB, Wang YC, Bray GM, Aguayo AJ (1994) Effects of ocular injury and administration of brain-derived neurotrophic factor on survival and regrowth of axotomized retinal ganglion cells. Proc Natl Acad Sci U S A 91:1632-1636.

Mattson MP, Camandola S (2001) NF- $\kappa$ B in neuronal plasticity and neurodegenerative disorders. J Clin Invest 107:247-254.

Meffert MK, Baltimore D (2005) Physiological functions for brain NF- $\kappa$ B. Trends Neurosci 28:37-43.

Metea MR, Newman EA (2006) Calcium signaling in specialized glial cells. Glia 54:650-655.

Mori N, Prager D (1996) Transactivation of the interleukin-1 $\alpha$ promoter by human T-cell leukemia virus type I and type II Tax proteins. Blood 87:3410-3417.

Nakazawa T, Morii H, Tamai M, Mori N (2005) Selective upregulation of $\mathrm{RB} 3 /$ stathmin4 by ciliary neurotrophic factor following optic nerve axotomy. Brain Res 1061:97-106.

Nakazawa T, Nakazawa C, Matsubara A, Noda K, Hisatomi T, She H, Michaud N, Hafezi-Moghadam A, Miller JW, Benowitz LI (2006) Tumor necrosis factor $\alpha$ mediates oligodendrocyte death and delayed retinal ganglion cell loss in a mouse model of glaucoma. J Neurosci 26:12633-12641.

Nakazawa T, Shimura M, Ryu M, Nishida K, Pagès G, Pouysségur J, Endo S (2008) ERK1 plays a critical protective role against $N$-methyl-Daspartate-induced retinal injury. J Neurosci Res 86:136-144.

Newman EA (2004) Glial modulation of synaptic transmission in the retina. Glia 47:268-274.

Noh KM, Yokota H, Mashiko T, Castillo PE, Zukin RS, Bennett MVL (2005) 
Blockade of calcium-permeable AMPA receptors protects hippocampal neurons against global ischemia-induced death. Proc Natl Acad Sci U S A 102:12230-12235.

Ogoshi F, Yin HZ, Kuppumbatti Y, Song B, Amindari S, Weiss JH (2005) Tumor necrosis-factor $\alpha$ (TNF- $\alpha$ ) induces rapid insertion of $\mathrm{Ca}^{2+}$ permeable $\alpha$-amino-3-hydroxyl-5-methyl-4-isoxazole-propionate (AMPA)/kainate ( $\mathrm{Ca}-\mathrm{A} / \mathrm{K})$ channels in a subset of hippocampal pyramidal neurons. Exp Neurol 193:384-393.

Oh H, Takagi H, Takagi C, Suzuma K, Otani A, Ishida K, Matsumura M, Ogura Y, Honda Y (1999) The potential angiogenic role of macrophages in the formation of choroidal neovascular membranes. Invest Ophthalmol Vis Sci 40:1891-1898.

Olfert ED, Cross BM, McWilliams AA (1993) The guide to the care and use of experimental animals, Ed 2, Ottawa: Canadian Council on Animal Care.

Osswald IK, Galan A, Bowie D (2007) Light triggers expression of philanthotoxin-insensitive $\mathrm{Ca}^{2+}$-permeable AMPA receptors in the developing rat retina. J Physiol 582:95-111.

Peinado-Ramón P, Salvador M, Villegas-Pérez MP, Vidal-Sanz M (1996) Effects of axotomy and intraocular administration of NT-4, NT-3, and brain-derived neurotrophic factor on the survival of adult rat retinal ganglion cells: a quantitative in vivo study. Invest Ophthalmol Vis Sci 37:489-500.

Perry VH (1981) Evidence for an amacrine cell system in the ganglion cell layer of the rat retina. Neuroscience 6:931-944.

Puro DG, Yuan JP, Sucher NJ (1996) Activation of NMDA receptorchannels in human retinal Müller glial cells inhibits inward-rectifying potassium currents. Vis Neurosci 13:319-326.

Remtulla S, Hallett PE (1985) A schematic eye for the mouse, and comparisons with the rat. Vision Res 25:21-31.

Sapieha PS, Duplan L, Uetani N, Joly S, Tremblay ML, Kennedy TE, Di Polo A (2005) Receptor protein tyrosine phosphatase $\sigma$ inhibits axon regrowth in the adult injured CNS. Mol Cell Neurosci 28:625-635.

Schmid JA, Birbach A (2008) I $\kappa$ B kinase $\beta$ (IKK $\beta /$ IKK2/IKBKB)—a key molecule in signaling to the transcription factor NF- $\kappa$ B. Cytokine Growth Factor Rev 19:157-165.

Schneider A, Martin-Villalba A, Weih F, Vogel J, Wirth T, Schwaninger M (1999) NF- $\kappa$ B is activated and promotes cell death in focal cerebral ischemia. Nat Med 5:554-559.

Schwaninger M, Inta I, Herrmann O (2006) NF- $\kappa$ B signalling in cerebral ischaemia. Biochem Soc Trans 34:1291-1294.

Seki M, Lipton SA (2008) Targeting excitotoxic/free radical signaling pathways for therapeutic intervention in glaucoma. Prog Brain Res 173:495-510.

Sensi SL, Yin HZ, Carriedo SG, Rao SS, Weiss JH (1999) Preferential Zn ${ }^{2+}$ influx through $\mathrm{Ca}^{2+}$-permeable AMPA/kainate channels triggers prolonged mitochondrial superoxide production. Proc Natl Acad Sci U S A 96:2414-2419.

Sensi SL, Ton-That D, Sullivan PG, Jonas EA, Gee KR, Kaczmarek LK, Weiss $\mathrm{JH}$ (2003) Modulation of mitochondrial function by endogenous $\mathrm{Zn}^{2+}$ pools. Proc Natl Acad Sci U S A 100:6157-6162.

Shakhov AN, Collart MA, Vassalli P, Nedospasov SA, Jongeneel CV (1990) $\kappa \mathrm{B}$-type enhancers are involved in lipopolysaccharide-mediated transcriptional activation of the tumor necrosis factor $\alpha$ gene in primary macrophages. J Exp Med 17:35-47.

Sharma S, Ball SL, Peachey NS (2005) Pharmacological studies of the mouse cone electroretinogram. Vis Neurosci 22:631-636.

Shimazawa M, Yamashima T, Agarwal N, Hara H (2005) Neuroprotective effects of minocycline against in vitro and in vivo retinal ganglion cell damage. Brain Res 1053:185-194.

Siliprandi R, Canella R, Carmignoto G (1993) Nerve growth factor pro- motes functional recovery of retinal ganglion cells after ischemia. Invest Ophthalmol Vis Sci 34:3232-3245.

Sitcheran R, Comb WC, Cogswell PC, Baldwin AS (2008) Essential role for epidermal growth factor receptor in glutamate receptor signaling to NF$\kappa$ B. Mol Cell Biol 28:5061-5070.

Stellwagen D, Malenka RC (2006) Synaptic scaling mediated by glial TNF- $\alpha$. Nature 440:1054-1059.

Stellwagen D, Beattie EC, Seo JY, Malenka RC (2005) Differential regulation of AMPA receptor and GABA receptor trafficking by tumor necrosis factor $\alpha$. J Neurosci 25:3219-3228.

Tezel G, Wax MB (2000) Increased production of tumor necrosis factor $\alpha$ by glial cells exposed to simulated ischemia or elevated hydrostatic pressure induces apoptosis in cocultured retinal ganglion cells. J Neurosci 20:8693-8700.

Tezel G, Li LY, Patil RV, Wax MB (2001) TNF- $\alpha$ and TNF- $\alpha$ receptor-1 in the retina of normal and glaucomatous eyes. Invest Ophthalmol Vis Sci 42:1787-1794.

Tezel G, Yang X, Yang J, Wax MB (2004) Role of tumor necrosis factor receptor-1 in the death of retinal ganglion cells following optic nerve crush injury in mice. Brain Res 996:202-212.

Thanos S (1991) The relationship of microglial cells to dying neurons during natural neuronal cell death and axotomy-induced degeneration of the rat retina. Eur J Neurosci 3:1189-1207.

Thorburn A (2004) Death receptor-induced cell killing. Cell Signal $16: 139-144$.

Tikka T, Fiebich BL, Goldsteins G, Keinanen R, Koistinaho J (2001) Minocycline, a tetracycline derivative, is neuroprotective against excitotoxicity by inhibiting activation and proliferation of microglia. J Neurosci 21:2580-2588.

Tsirka SE, Gualandris A, Amaral DG, Strickland S (1995) Excitotoxininduced neuronal degeneration and seizure are mediated by tissue plasminogen activator. Nature 377:340-344.

Velier JJ, Ellison JA, Kikly KK, Spera PA, Barone FC, Feuerstein GZ (1999) Caspase- 8 and caspase- 3 are expressed by different populations of cortical neurons undergoing delayed cell death after focal stroke in the rat. J Neurosci 19:5932-5941.

Vogt C, Hailer NP, Ghadban C, Korf HW, Dehghani F (2008) Successful inhibition of excitotoxic neuronal damage and microglial activation after delayed application of interleukin-1 receptor antagonist. J Neurosci Res 86:3314-3321.

Weishaupt JH, Diem R, Kermer P, Krajewski S, Reed JC, Bähr M (2003) Contribution of caspase- 8 to apoptosis of axotomized rat retinal ganglion cells in vivo. Neurobiol Dis 13:124-135.

Wood PL (1995) Microglia as a unique cellular target in the treatment of stroke: potential neurotoxic mediators produced by activated microglia. Neurol Res 17:242-248.

Yan X, Tezel G, Wax MB, Edward DP (2000) Matrix metalloproteinases and tumor necrosis factor $\alpha$ in glaucomatous optic nerve head. Arch Ophthalmol 118:666-673.

Yu DY, Cringle SJ (2006) Oxygen distribution in the mouse retina. Invest Ophthalmol Vis Sci 47:1109-1112.

Yuan L, Neufeld AH (2000) Tumor necrosis factor $\alpha$ : a potentially neurodestructive cytokine produced by glia in the human glaucomatous optic nerve head. Glia 32:42-50.

Zhang D, Sucher NJ, Lipton SA (1995) Co-expression of AMPA/kainate receptor-operated channels with high and low $\mathrm{Ca}^{2+}$ permeability in single rat retinal ganglion cells. Neuroscience 67:177-188.

Zhang J, Diamond JS (2006) Distinct perisynaptic and synaptic localization of NMDA and AMPA receptors on ganglion cells in rat retina. J Comp Neurol 498:810-820. 